\title{
Genetic Diversity of Soil Bacteria
}

\author{
Carmine Crecchio
}

Department of Soil, Plant and Food Sciences, University of Bari Aldo Moro, Via Amendola 165/a, 70126 Bari, Italy; carmine.crecchio@uniba.it

Received: 24 October 2020; Accepted: 28 October 2020; Published: 29 October 2020

\begin{abstract}
The Special Issue "Genetic Diversity of Soil Bacterial Communities" collected research and review articles addressing some relevant and unclear aspects of the composition and functioning of bacterial communities in rich or marginal agricultural soils, in field trials as well as in laboratory-scale experiments, at different latitudes and under different types of management.
\end{abstract}

Keywords: soil bacteria diversity; bacteriobiome; soil fertility

Soil has been defined as a "black box" because of its complexity and of the difficulties that scientists have faced in recent decades to unravel the composition and, moreover, the functions of its biotic and abiotic components. Soil has been recognized to play a key role in the biosphere, as most of the carbon and nutrient fluxes occur in its top $10 \mathrm{~cm}$ profile, and it is a habitat that is tremendously rich in species that contribute to plant growth and health that, in turn, may affect human beings [1].

Among the biotic components, the soil microbiome, mainly bacteria and at a lower scale fungi, plays an important role as a driver of the living soil, being responsible for the main biogeochemical cycles involved in the transformation of nutrients and their flows from soil to plants [2]. On the other hand, the soil microbiome is strongly affected by anthropogenic activities such as intensive agriculture, different soil management approaches, and environmental contamination [3,4].

So, it is very important to deeply investigate the structure and functioning of whole microbial communities as well as to characterize single species, i.e., those potentially useful in agriculture as promoters of plant nutrition and protection. The papers in this Special Issue are an example of how many different aspects should be investigated by biochemical, microbiological and molecular approaches, and reveal how varied and still not completely understood this topic is.

A research article investigated how various fodder and lawn grass species and their functional forms modify the soil bacteriobiome, as determined by $16 \mathrm{~S}$ rDNA sequencing up to the genera level, as well as the main enzyme activities of microbial origin [5].

A similar approach was used to investigate the relevance of cultivation regimes of three crop species, leading the authors to conclude that both species and management contribute to the modification of the rhizosphere soil microbiome as well as reliable biochemical indicators related to soil fertility [6].

Yaghoubi Khanghahi and colleagues investigated the influence of long-term land use intensities on: (i) some microbiological and biochemical parameters, all contributing to the calculation of the Biological Fertility Index (BFI); (ii) total bacterial quantification in soil, determining the rRNA gene copy number by qPCR; (iii) $\alpha$ diversity and community composition [7].

A research paper by Marques and colleagues reports that sweet potato genotypes and their growth stage influence rhizosphere bacterial composition, in particular that of microbial groups involved in phosphate mineralization and nitrogen fixation, both playing a fundamental role in plant nutrition processes [8].

The Special Issue also publishes a review by Moura and colleagues, reporting the state of the art of the symbiotic nitrogen fixation, deepening, in particular, the interactions existing between rhizobia and legume species, and how such association provides benefits not only in the efficiency of nitrogen 
use, but also in soil carbon sequestration, stabilization of soil organic matter, soil penetration resistance and soil fertility in tropical environments [9].

We expect the above mentioned articles will be of interest to the scientific community and complement ongoing global efforts to reveal secrets of the "black box", soil and its bacterial inhabitants.

Funding: This research received no external funding.

Conflicts of Interest: The author declares no conflict of interest.

\section{References}

1. Nannipieri, P.; Ascher, J.; Ceccherini, M.T.; Landi, L.; Pietramellara, G.; Renella, G. Microbial diversity and soil functions. Eur. J. Soil Sci. 2017, 68, 12. [CrossRef]

2. Tate, R.L., III. Soil Microbiology; Wiley: New York, NY, USA, 1995.

3. Hendgen, M.; Hoppe, B.; Doring, J.; Friedel, M.; Kauer, R.; Frisch, M.; Dahl, A.; Kellner, H. Effects of different management regimens on microbial biodiversity in vineyard soils. Sci. Rep. 2018, 8, 9393. [CrossRef] [PubMed]

4. Kennedy, A.C.; Smith, K.L. Soil microbial diversity and sustainability of agricultural soils. Plant Soil 1995, 170, 75. [CrossRef]

5. Borowik, A.; Wyszkowska, J.; Kucharski, J. Impact of Various Grass Species on Soil Bacteriobiome. Diversity 2020, 12, 212. [CrossRef]

6. Wyszkowska, J.; Borowik, A.; Olszewski, J.; Kucharski, J. Soil Bacterial Community and Soil Enzyme Activity Depending on the Cultivation of Triticum aestivum, Brassica napus, and Pisum sativum ssp. arvense. Diversity 2019, 11, 246. [CrossRef]

7. Yaghoubi Khanghahi, M.; Murgese, P.; Strafella, S.; Crecchio, C. Soil Biological Fertility and Bacterial Community Response to Land Use Intensity: A Case Study in the Mediterranean Area. Diversity 2019, 11, 211. [CrossRef]

8. Marques, J.M.; Mateus, J.M.; da Silva, T.F.; Couto, C.R.A.; Blank, A.F.; Seldin, L. Nitrogen Fixing and Phosphate Mineralizing Bacterial Communities in Sweet Potato Rhizosphere Show a Genotype-Dependent Distribution. Diversity 2019, 11, 231. [CrossRef]

9. Moura, E.G.; Carvalho, C.S.; Bucher, C.P.C.; Souza, J.L.B.; Aguiar, A.C.F.; Ferraz Junior, A.S.L.; Bucher, C.A.; Coelho, K.P. Diversity of Rhizobia and Importance of Their Interactions with Legume Trees for Feasibility and Sustainability of the Tropical Agrosystems. Diversity 2020, 12, 206. [CrossRef]

Publisher's Note: MDPI stays neutral with regard to jurisdictional claims in published maps and institutional affiliations.

(C) 2020 by the author. Licensee MDPI, Basel, Switzerland. This article is an open access article distributed under the terms and conditions of the Creative Commons Attribution (CC BY) license (http://creativecommons.org/licenses/by/4.0/). 